\title{
Activation of muscarinic acetylcholine receptors elicits pigment granule dispersion in retinal pigment epithelium isolated from bluegill
}

\author{
Alfredo González III, Elizabeth L Crittenden and Dana M García*
}

Address: Department of Biology, Texas State University-San Marcos, San Marcos, Texas 78666, USA

Email: Alfredo González - trinityfinancial@sbcglobal.net; Elizabeth L Crittenden - ec1034@txstate.edu; Dana M García* - dana_garcia@txstate.edu

* Corresponding author

Published: 13 July 2004

BMC Neuroscience 2004, 5:23 doi:10.1 |86/|47|-2202-5-23
Received: 04 March 2004

Accepted: I 3 July 2004

This article is available from: http://www.biomedcentral.com/I47I-2202/5/23

( 2004 González et al; licensee BioMed Central Ltd. This is an Open Access article: verbatim copying and redistribution of this article are permitted in all media for any purpose, provided this notice is preserved along with the article's original URL.

\begin{abstract}
Background: In fish, melanin pigment granules in the retinal pigment epithelium disperse into apical projections as part of the suite of responses the eye makes to bright light conditions. This pigment granule dispersion serves to reduce photobleaching and occurs in response to neurochemicals secreted by the retina. Previous work has shown that acetylcholine may be involved in inducing light-adaptive pigment dispersion. Acetylcholine receptors are of two main types, nicotinic and muscarinic. Muscarinic receptors are in the G-protein coupled receptor superfamily, and five different muscarinic receptors have been molecularly cloned in human. These receptors are coupled to adenylyl cyclase, calcium mobilization and ion channel activation. To determine the receptor pathway involved in eliciting pigment granule migration, we isolated retinal pigment epithelium from bluegill and subjected it to a battery of cholinergic agents.
\end{abstract}

Results: The general cholinergic agonist carbachol induces pigment granule dispersion in isolated retinal pigment epithelium. Carbachol-induced pigment granule dispersion is blocked by the muscarinic antagonist atropine, by the $M_{1}$ antagonist pirenzepine, and by the $M_{3}$ antagonist 4DAMP. Pigment granule dispersion was also induced by the $M_{1}$ agonist 4-[N-(4-chlorophenyl) carbamoyloxy]-4-pent-2-ammonium iodide. In contrast the $M_{2}$ antagonist AF-DX II 6 and the $M_{4}$ antagonist tropicamide failed to block carbachol-induced dispersion, and the $M_{2}$ agonist arecaidine but-2-ynyl ester tosylate failed to elicit dispersion.

Conclusions: Our results suggest that carbachol-mediated pigment granule dispersion occurs through the activation of $M_{\text {odd }}$ muscarinic receptors, which in other systems couple to phosphoinositide hydrolysis and elevation of intracellular calcium. This conclusion must be corroborated by molecular studies, but suggests $\mathrm{Ca}^{2+}$-dependent pathways may be involved in light-adaptive pigment dispersion. 


\section{Background}

The retinal pigment epithelium (RPE) of teleost fishes undergoes diurnal changes in the position of its pigment granules, dispersing them into long apical projections in the light and aggregating them into the cell body in the dark (see [1]). These movements are coordinated with changes in the position of rod and cone photoreceptors and are thought to optimize light capture by the relevant photoreceptors (rods in the dark; cones in the light). The RPE is not itself sensitive to light, and several lines of evidence suggest that it relies on paracrine signals from the retina to accomplish appropriate movements (see [2]). Although light-adaptive pigment granule movements occur only in "lower" vertebrate classes, the question of how the retina communicates with the RPE is relevant to normal retinal and RPE function in many vertebrate species and may contribute to greater understanding of the function of the pineal organ as well. RPE is crucial for normal visual function, and defects in the RPE are associated with a number of diseases that lead to retinal degeneration and blindness (for an example, see [3]).

It was established 15 years ago that dopamine was an important light signal in the retina of green sunfish $[2,4]$ and bullfrog [5]. In green sunfish, pharmacological studies indicated that dopamine works through $\mathrm{D}_{2}$ receptors [2], which are negatively coupled to adenylyl cyclase and cause cAMP levels in cells to decrease [6]. However, work by others $[7,8]$ raised the possibility that other neurochemicals could be involved in regulating light adaptation in fishes. The finding that the cholinergic agonist carbachol induces pigment granule dispersion in green sunfish was the first evidence that retinomotor movements can be elicited by activating acetylcholine receptors in addition to dopamine receptors [9].

Acetylcholine has been shown to act through two major types of receptors in other systems, nicotinic and muscarinic receptors (see [10]). Nicotinic receptors are ligandgated ion channels, while muscarinic receptors belong to the G-protein coupled receptor superfamily of seven transmembrane domain proteins. Five types of muscarinic receptor $\left(M_{1}-M_{5}\right)$ have been defined in mammals (see [10]), and recent studies have demonstrated that zebrafish have at least two muscarinic receptor genes [11]. Heterologous systems in which a single, cloned receptortype is expressed in cell types not normally expressing muscarinic receptors have demonstrated the receptors to be coupled to multiple intracellular signaling pathways. In most native systems, $M_{1}, M_{3}$ and $M_{5}$ receptors are coupled to phosphoinositide hydrolysis and calcium mobilization while $\mathrm{M}_{2}$ and $\mathrm{M}_{4}$ receptors are coupled to adenylyl cyclase through $G_{\text {inhibitory }}$ proteins. Additionally, in some cases, $\mathrm{M}_{2}$ receptors are also coupled to potassium channels (see $[10,12,13])$.

We report here that carbachol-induced pigment granule dispersion occurs in RPE isolated from bluegill (Lepomis macrochirus). Furthermore, our results using a pharmacological approach suggest that carbachol acts on one or more of the "odd" subtypes $\left(\mathrm{M}_{1}, \mathrm{M}_{3}\right.$ or $\left.\mathrm{M}_{5}\right)$ of muscarinic receptors to elicit light adaptive pigment granule dispersion. We suggest, therefore, that acetylcholine may act in concert with dopamine or other mechanisms which reduce cellular cyclic adenosine monophosphate levels to assure appropriate, light adaptive pigment granule movement in the retinas of fishes.

\section{Results}

\section{Forskolin induces pigment granule aggregation}

The adenylyl cyclase activator forskolin induced pigment granule aggregation in isolated RPE in a dose-dependent manner as determined by evaluating the pigment position using the pigment index (PI; see [14]) (Table 1). Cells incubated in $10 \mu \mathrm{M}$ forskolin were significantly aggregated compared to control samples incubated in isolation buffer alone $(\mathrm{p}<0.05)$. Therefore, in subsequent experiments tissue was induced to aggregate pigment by incubating tissue in $10 \mu \mathrm{M}$ forskolin prior to treatment with cholinergic agents.

Table I: Forskolin induces pigment aggregation in a dose-dependent manner.

\begin{tabular}{|c|c|c|}
\hline Concentration & Pigment Index \pm SEM & $n$ \\
\hline $0 \mu \mathrm{M}$ & $0.98 \pm 0.00$ & 6 \\
\hline $0.1 \mu \mathrm{M}$ & $0.93 \pm 0.00$ & 3 \\
\hline $\mathrm{I} \mu \mathrm{M}$ & $0.89 \pm 0.01$ & 3 \\
\hline $10 \mu \mathrm{M}$ & $0.75 \pm 0.02$ & 2 \\
\hline $100 \mu \mathrm{M}$ & 0.71 & I \\
\hline
\end{tabular}

RPE was isolated from dark-adapted bluegill and incubated 45 minutes in increasing concentrations of forskolin. Tissue fixed prior to incubation in forskolin had a pigment index of $0.97 \pm 0.00(n=6$ fish). Maximal aggregation was attained by concentrations as low as $10 \mu M$. 

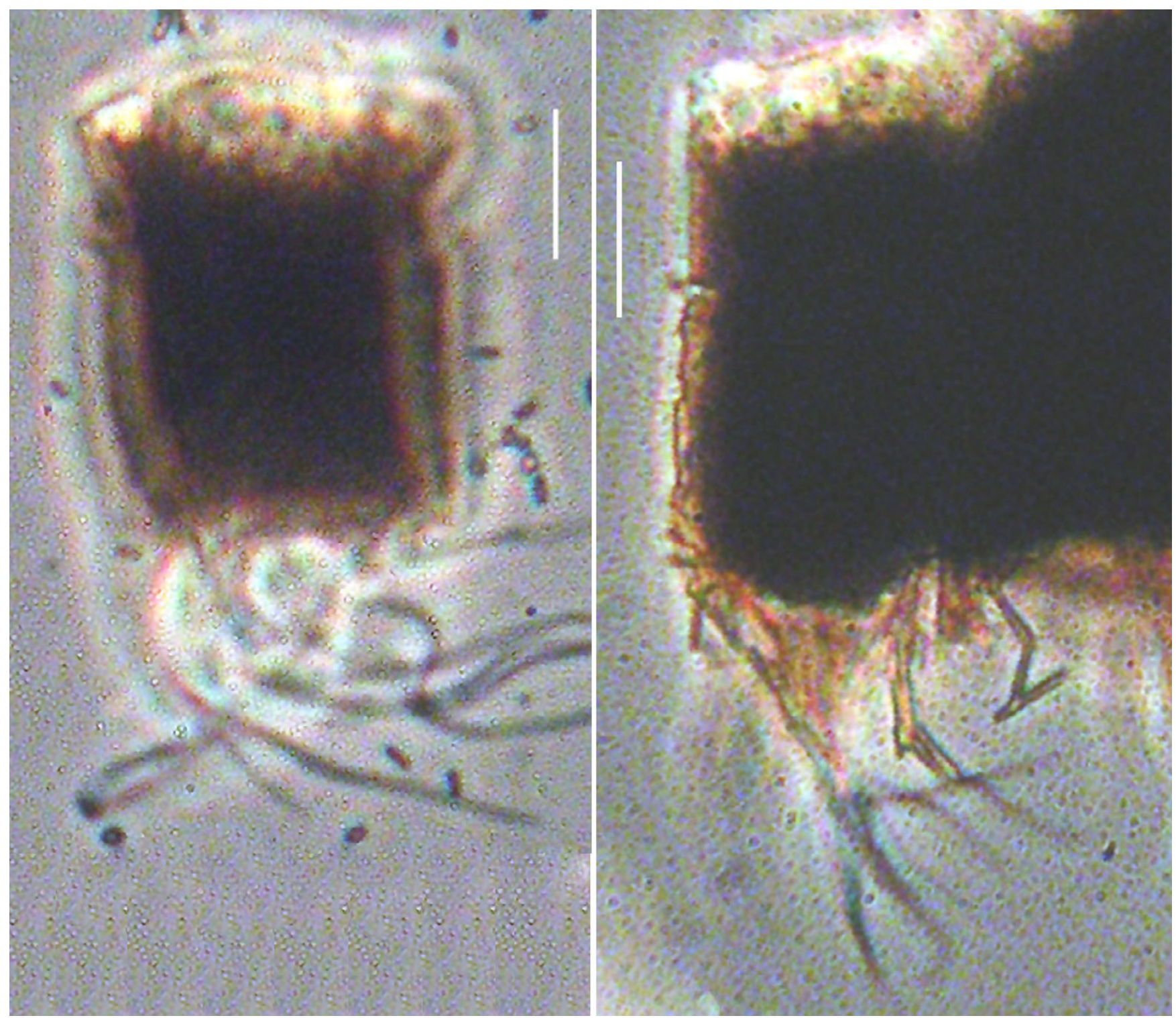

\section{Figure I}

Phase contrast images illustrate RPE with pigment granules aggregated (left) and RPE with pigment granules dispersed (right). RPE were isolated from bluegill and treated with $10 \mu \mathrm{M}$ forskolin for 45 minutes to induce aggregation. A subset was fixed overnight and prepared for microscopy. In a second subset forskolin was washed out, and RPE were treated with $100 \mathrm{nM}$ carbachol to induce dispersion. After 45 minutes, the second subset was fixed overnight and prepared for microscopy. Images were obtained using a digital camera focused through the oculars of a Zeiss microscope. Scale bars $=10 \mu \mathrm{m}$.

\section{Carbachol induces pigment granule dispersion by activating muscarinic receptors}

The application of the general cholinergic agonist carbachol to isolated RPE that had been pretreated with forskolin caused pigment granule dispersion in a dosedependent manner (Figures 1 and 2). The pigment index is the ratio of the length of the cell occupied by pigment to the total length of the cell, and approaches unity as the pigment granules become increasingly dispersed. Cells treated with $10 \mathrm{nM}$ carbachol had significantly higher pigment indices ( $\mathrm{PI}=0.84 \pm 0.04 ; \mathrm{n}=6)$ than control cells incubated in the absence of carbachol $(\mathrm{PI}=0.73 \pm 0.03 ; \mathrm{n}$ = 6) $(\mathrm{p}<0.05)$; although, the latter underwent slight, statistically significant dispersion, as well, relative to the forskolin-treated cells. Cells treated with concentrations greater than $10 \mathrm{nM}$ did not disperse significantly further. 


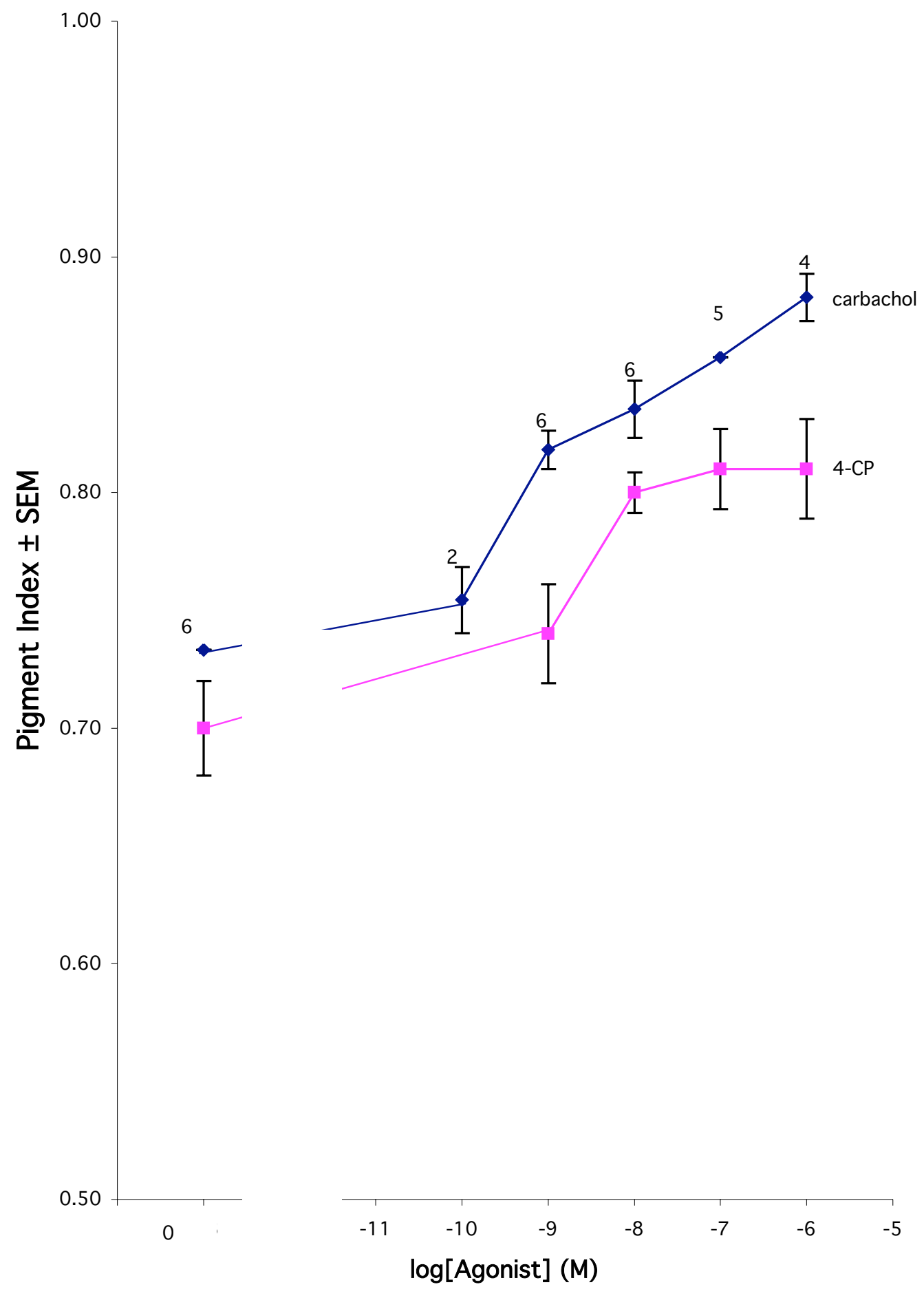

Figure 2

Carbachol induces pigment granule dispersion in isolated RPE. RPE were isolated from bluegill and, following treatment with forskolin to induce aggregation, were subjected to increasing concentrations of either carbachol or the $\mathrm{MI}$ receptor agonist 4-[N-(4-chlorophenyl) carbamoyloxy]-4-pent-2-ammonium iodide ( $\mathrm{n}=4$ at each concentration, except as noted for carbachol). Both agonists induced dose-dependent, saturable pigment granule dispersion with the former eliciting maximal dispersion at concentrations as low as I nM and the latter at concentrations as low as $10 \mathrm{nM}$. In contast, the M2 agonist arecaidine but-2-ynyl ester tosylate did not effectively stimulate pigment granule dispersion (see Table 2). 
Even though the maximal effect of carbachol was seen with the $10 \mathrm{nM}$ treatment, $100 \mathrm{nM}$ carbachol was used in subsequent experiments testing antagonist effects, to ensure maximal response.

In order to examine if muscarinic receptors were involved in mediating carbachol-induced dispersion, we tested the ability of atropine, a muscarinic antagonist that blocks $\mathrm{M}_{1}-\mathrm{M}_{5}$ receptors, to inhibit carbachol-induced dispersion. We found atropine to be a highly effective blocker of carbachol-induced dispersion (Figure 3). Indeed, at concentrations as low as $10 \mathrm{pM}$, atropine completely inhibited carbachol-induced dispersion. This inhibition is illustrated by the observation that the mean pigment index of cells treated in carbachol alone $(P I=0.83 \pm 0.02)$ is significantly higher compared to the mean pigment index of cells treated concurrently with $10 \mathrm{pM}$ atropine and $100 \mathrm{nM}$ carbachol $(\mathrm{PI}=0.69 \pm 0.03)(\mathrm{p}<0.05)$.

\section{Carbachol exerts its effects through an M-odd receptor}

A battery of pharmacological agents was tested to better characterize the receptor subtype involved in carbacholinduced pigment dispersion. Firstly pirenzepine, an $M_{1}$ blocker, was examined and found to be effective at blocking carbachol-induced dispersion (Figure 3) with $10 \mathrm{nM}$ pirenzepine treatment $(\mathrm{PI}=0.67 \pm 0.02)$ being significantly more aggregated than the control incubated in carbachol alone $(\mathrm{PI}=0.81 \pm 0.01)$. However, at concentrations greater than $10 \mathrm{nM}$, pirenzepine-based inhibition was not significantly increased, suggesting receptor saturation at $10 \mathrm{nM}$ pirenzepine.

Secondly, after discovering the $\mathrm{M}_{1}$ blocker pirenzepine was effective in inhibiting carbachol-induced dispersion, the efficacy of the $\mathrm{M}_{1}$ agonist, 4 -[N-(4-chlorophenyl) carbamoyloxy]-4-pent-2-ammonium iodide, hereafter referred to as $4-\mathrm{CP}$, in inducing pigment granule dispersion was examined. 4-CP is a potent stimulator of pigment granule dispersion (Figure 2 ). Indeed, the pigment granule position $(\mathrm{PI}=0.80 \pm 0.01)$ in the $10 \mathrm{nM}$ treatment was more dispersed than cells treated in buffer alone $(\mathrm{PI}=$ $0.70 \pm 0.01)(\mathrm{p}<0.05)$. In fact, $10 \mathrm{nM} 4$-CP induced the maximal response $(\mathrm{p}<0.05)$, as greater concentrations did not cause pigment granules to disperse significantly further.

Next the $\mathrm{M}_{3}$ antagonist 4-DAMP was tested and was found effective in blocking carbachol-induced dispersion (Figure 3). Maximal inhibition occurred in the $10 \mathrm{nM}$ treatment group ( $P I=0.65 \pm 0.02)$, with cells incubated in this treatment having significantly more aggregated pigment than the control cells incubated in carbachol alone $(\mathrm{PI}=0.75 \pm$ $0.00)(\mathrm{p}<0.05)$.
Following examination of agents selective for $\mathrm{M}_{\text {odd }}$ receptors, the effects of $M_{\text {even }}$ selective agents were examined. The ability of the $M_{2}$ blocker, AF-DX 116, and the $M_{4}$ inhibitor tropicamide to inhibit carbachol-induced pigment dispersion was examined. AF-DX 116 was not effective in blocking carbachol-induced dispersion (Figure 3). The pigment index of the control cells treated with carbachol, but with no inhibitor $(\mathrm{PI}=0.87 \pm 0.01)$ was greater than that from cells treated in forskolin alone $(\mathrm{PI}=0.68 \pm$ 0.01) ( $\mathrm{p}<0.05)$. Yet, the pigment indices of RPE treated with both AF-DX 116 and carbachol were not significantly different from pigment indices of the cells treated with carbachol alone. Similarly, there was no significant difference between the pigment index of control cells treated with carbachol and those treated with both carbachol and tropicamide.

Finally the $\mathrm{M}_{2}$ agonist arecaidine but-2-ynyl ester tosylate (arecaidine) did not induce pigment granule dispersion. Neither the pigment indices of the control cells incubated in $0.01 \%$ DMSO, nor the pigment indices of cells treated in arecaidine were significantly different from cells treated in forskolin alone (Table 2).

\section{Discussion}

Here we show that carbachol induces pigment granule dispersion in RPE isolated from bluegill (Lepomis macrochirus). The maximal effect of carbachol was seen at concentrations as low as $10 \mathrm{nM}$. This result is consistent with García's [9] earlier study in which carbachol induced pigment granule dispersion in isolated RPE of green sunfish (Lepomis cyanellus). Using bluegill, we have shown that carbachol-induced pigment granule dispersion is not species-specific and that carbachol-induced pigment dispersion is dose-dependent and saturable, indicating a receptor-mediated process. Atropine, a general muscarinic antagonist, was shown to block pigment granule dispersion, suggesting muscarinic receptors mediate carbacholinduced dispersion. Furthermore, because $M_{1}$ and $M_{3}$ antagonists strongly inhibited pigment granule dispersion induced by carbachol and because the $\mathrm{M}_{1}$ agonist 4-CP induced pigment granule dispersion, the involvement of $M_{1}$ or $M_{3}$ receptors is suggested. The involvement of an $M_{5}$ receptor cannot be addressed pharmacologically at this time since no $\mathrm{M}_{5}$-selective agents are currently commercially available.

Although the results from the pharmacological studies with muscarinic receptor agonists and antagonists are internally consistent with the interpretation that $M_{\text {odd }}$ receptors are involved in mediating carbachol-induced dispersion $\left(\mathrm{M}_{\text {odd }}\right.$ reagents are effective; $M_{\text {even }}$ are not), drug studies in embryonic chick have illustrated that pharmacological results taken by themselves can be misleading. Pirenzepine, although described as an $M_{1}$-selective 


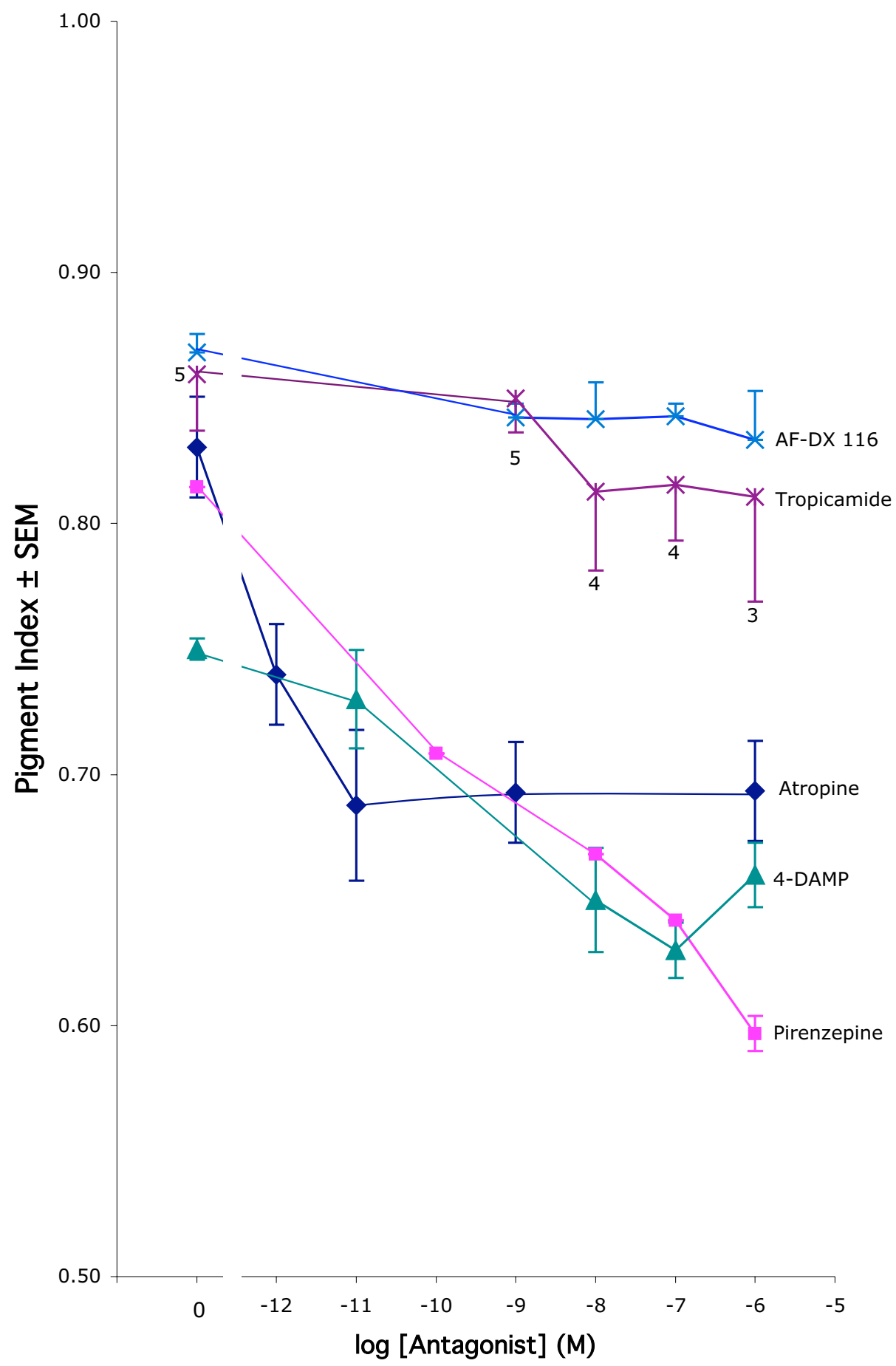

Figure 3

Atropine and $M_{\text {odd }}$ muscarinic agonists block carbachol-induced pigment granule dispersion. RPE were isolated from bluegill, and following treatment with forskolin were subjected to $100 \mathrm{nM}$ carbachol and varying concentrations of muscarinic receptor antagonists $(n=4$, except as noted for tropicamide). The general muscarinic receptor antagonist atropine completely blocked carbachol-induced dispersion at concentrations as low as $10 \mathrm{pM}$. The $\mathrm{MI}$ antagonist pirenzepine and the M3 antagonist 4-DAMP also blocked dispersion at concentrations as low as $10 \mathrm{nM}$. In contrast, the M2 antagonist AF-DX II 6 and the M4 antagonist tropicamide were ineffectual at blocking carbachol-induced pigment dispersion, even at concentrations as high as I $\mu \mathrm{M}$. 
Table 2: Arecaidine but-2-ynyl ester tosylate does not induce pigment granule dispersion

\begin{tabular}{cccc}
\hline Concentration & Pigment Index \pm SEM & $n$ \\
\hline $0 \mathrm{nM}$ & $0.74 \pm 0.01$ & 4 \\
$\mathrm{I} \mathrm{nM}$ & $0.77 \pm 0.03$ & 4 & 4 \\
$\mathrm{I} \mathrm{nM}$ & $0.80 \pm 0.02$ & 4 & 4 \\
$100 \mathrm{nM}$ & $0.78 \pm 0.02$ & 4 \\
\hline $\mathrm{IM}$ & $0.78 \pm 0.01$ & \\
\hline
\end{tabular}

RPE was isolated from dark-adapted bluegill and, following incubation for 45 minutes in $10 \mu \mathrm{M}$ forskolin, was incubated an additional 45 minutes in increasing concentrations of arecaidine but-2-ynyl ester tosylate or in a DMSO control. At the end of incubation in forskolin, RPE had a pigment index of $0.72 \pm 0.02(n=4$ fish); the $0.01 \%$ DMSO control had a pigment index of $0.69 \pm 0.02(n=2$ fish).

antagonist in both mammals and trout [15,16], avidly binds $\mathrm{M}_{2}$ receptors in chick [16] and may bind $\mathrm{M}_{4}$ receptors in other systems as well [17]. Furthermore, Hsieh and Liao [11] have reported that pirenzepine binds the $M_{2}$ receptor they have isolated from zebrafish with a submicromolar dissociation constant. Therefore, a molecular characterization of the receptor subtype(s) expressed by bluegill RPE must be done before a definitive assignment can be made. These studies are currently underway in our laboratory.

Given the ambiguity associated with the pharmacology of muscarinic receptors in non-mammalian vertebrates, the question of which muscarinic receptor is involved in carbachol-induced pigment granule dispersion remains open. Based on our current knowledge of the signaling pathways involved in regulating pigment granule movement, the simplest model for muscarinic receptor involvement would invoke an $M_{\text {even }}$ receptor negatively coupled to adenylyl cyclase through $\mathrm{G}_{\text {inhibitory }}$ proteins (Figure 4). According to this model, activation of the receptor would lead to inhibition of adenylyl cyclase, resulting in decreased $\mathrm{CAMP}_{\mathrm{i}}$ levels due to degradation by phosphodiesterases, efflux via organic anion transporters, or both. As a consequence of decreased $\mathrm{CAMP}_{\mathrm{i}}$, the activity of cAMPdependent protein kinase (PKA) would diminish. The activity of protein phosphatases would then tip the balance between phosphoproteins and their dephosphorylated counterparts toward the latter, and this, in turn, would lead to pigment granule dispersion.

Consistent with this model are the observations that treatments expected to elevate $\mathrm{CAMP}_{\mathrm{i}}$ induce pigment granule aggregation in RPE isolated from bluegill (Table 1), green sunfish [2,14,18], and blue-striped grunt [19]. Furthermore, King-Smith et al. [20] demonstrated that simply washing away exogenously applied, extracellular cAMP was sufficient to induce pigment granule dispersion in both isolated RPE sheets and dissociated RPE cells. Impor- tantly, elevation of cAMP caused aggregation and washout of cAMP caused dispersion irrespective of the external or internal concentrations of calcium. We have also observed exogenous cAMP induces aggregation in RPE isolated from bluegill, and its washout is sufficient to induce dispersion (García, unpublished observations). Presumably, in both bluegill and green sunfish RPE removing extracellular cAMP not only eliminated the supply of cAMP available for import via organic anion transporters [18], but also reversed the gradient, favoring its export. In addition, microinjection of the PKA inhibitor $\mathrm{PKI}_{5-24}$ amide into dissociated cells isolated from green sunfish resulted in pigment granule dispersion (García, unpublished observations).

The central importance of cAMP in regulating pigment granule position is also suggested by studies conducted on dermal melanophores of tilapia (Tilapia mossambica) [2125], black tetra (Gymnocorymbus ternetzii) [26], and angelfish (Pterophyllum scalare) [27] among others (reviewed in [28]). In each of these cases, increased $\mathrm{CAMP}_{\mathrm{i}}$ is associated with pigment granule dispersion and decreased $\mathrm{CAMP}_{\mathrm{i}}$ with pigment granule aggregation. Studies done on permeabilized melanophores from tilapia demonstrated that the direction of pigment granule movement was dictated by the addition and removal of cAMP [22] and that pigment granule dispersion could be induced by addition of the catalytic subunit of PKA [25]. Similarly, in melanophores isolated from black tetra cAMP levels measured immunohistochemically tracked closely with extent of pigment granule movement toward the plus-end of microtubules during pigment granule dispersion [26]. Sammak et al. [27] observed fluxes in $\mathrm{CAMP}_{\mathrm{i}}$ as well as $\mathrm{Ca}^{2+}$ levels in melanophores isolated from angelfish, but found that only the former were necessary and sufficient to influence pigment granule position, whereas the latter were neither necessary nor sufficient to influence pigment granule movement. Similarly, Kotz and McNiven [29] presented pharmacological evidence suggesting that reducing 


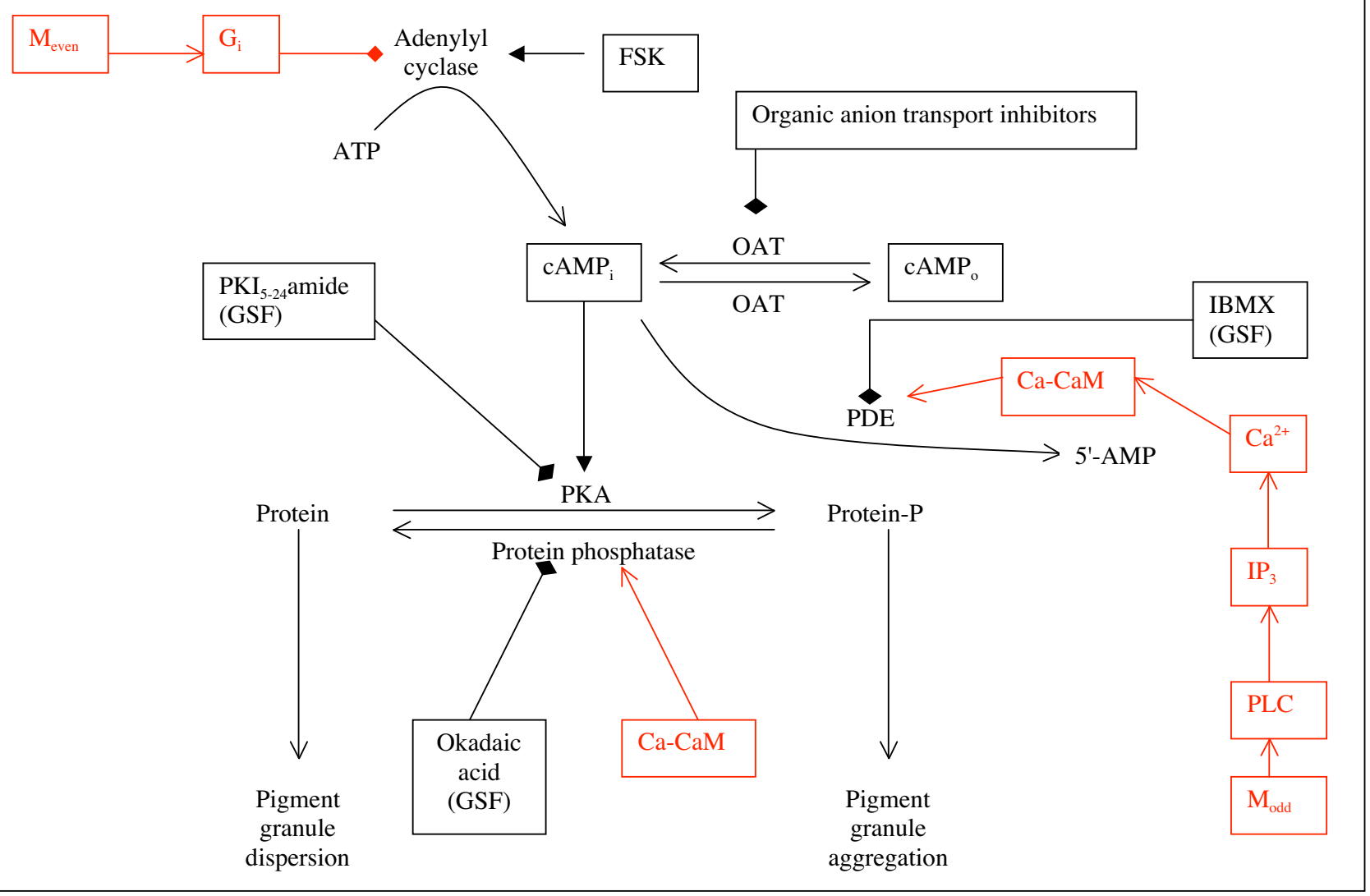

Figure 4

Schematic diagram illustrating second messenger pathways possibly involved in regulating pigment granule movement in RPE and entry points for muscarinic regulation. Most evidence suggests a central role for cAMPdependent phosphorylation events in the induction of pigment granule aggregation in retinal pigment epithelium. Shown in black boxes in this schematic diagram are players in this pathway that have been manipulated experimentally in RPE isolated from bluegill, green sunfish or both. Pathways shown in red indicate possible regulatory inputs from muscarinic receptor activation (see text for a more extensive explanation as well as references). Abbreviations used are as follows (listed alphabetically): 5'-AMP, 5'-adenosine monophosphate; $\mathbf{C a}^{2+}$, calcium; Ca-CaM, calcium-calmodulin complex; $\mathbf{C A M P}$, intracellular cyclic adenosine monophosphate; $\mathbf{C A M P}_{\mathbf{o}}$, extracellular cyclic adenosine monosphosphate; FSK, forskolin; $\mathbf{G}_{\mathrm{i}}$, inhibitory GTP-binding protein; GSF, green sunfish (indicating that this experimental manipulation was only performed on RPE isolated from green sunfish); IBMX, isobutylmethylxanthine (a phosphodiesterase inhibitor); I $\mathbf{P}_{\mathbf{3}}$, inositol trisphosphate; $\mathbf{M}_{\text {even, }}$, muscarinic acetylcholine receptor subtype 2 or 4 ; $\mathbf{M}_{\text {odd }}$, muscarinic acetylcholine receptor subtype I, 3, or 5; OAT, organic anion transporter; PDE, phosphodiesterase; $\mathbf{P K I}_{\mathbf{5 - 2 4}}$ amide, cAMP-dependent protein kinase inhibitory peptide (amino acids 5-24) with an amide adduct; PLC, phospholipase C; Protein-P, a phosphoprotein; arrows terminating in diamonds signify inhibitory effects; arrows terminating in triangles or barbs signify stimulatory effects.

CAMP $_{i}$ was sufficient to stimulate aggregation in squirrelfish melanophores, while $\mathrm{Ca}^{2+}$ dynamics appeared variable and unimportant.

Although the simplest model for muscarinic regulation would be through G-protein-mediated inhibition of adenylyl cyclase, a model involving activation of phospholi- pase $\mathrm{C}$ must also be considered. While evidence exists in heterologous expression systems for $M_{1}$ receptor-based inhibition of adenylyl cyclase [17], $M_{\text {odd }}$ receptor activation is more typically associated with activation of phospholipase $\mathrm{C}$. In general, phospholipase $\mathrm{C}$ catalyzes the conversion of phosphatidylinositol bisphosphate to diacylglycerol and inositol trisphosphate $\left(\mathrm{IP}_{3}\right)$. $\mathrm{IP}_{3}$, in turn, 
activates ligand-gated $\mathrm{Ca}^{2+}$ channels located on intracellular storage organelles, leading to release of $\mathrm{Ca}^{2+}$ from these stores, and an elevation of cytoplasmic free $\mathrm{Ca}^{2+}$. Cytoplasmic $\mathrm{Ca}^{2+}$ typically binds to and activates calmodulin, which modulates the activities of a number of enzymes, including certain phosphodiesterases (e.g. PDE1) as well as some protein phosphatases (e.g. calcineurin). In the former case, increasing phosphodiesterase activity would decrease cAMP levels, leading to decreased PKA activity and decrease in the rate of phosphorylation of PKA-target proteins. In addition, if protein phosphatases were activated, the tendency for target proteins to be dephosphorylated would be further enhanced. It should be noted that calcineurin has been shown to be involved in regulating pigment granule movement in melanophores isolated from tilapia [25]. In either case (or both cases), the balance would be shifted to dephosphorylated proteins which, though not yet identified, seem to favor pigment granule dispersion.

The results we present herein are consistent with this model in that agents characterized as $M_{\text {odd }}$-selective in other systems affected the pigment granule movement under study, while $\mathrm{M}_{\text {even }}$-selective agents did not [10]. However, one wonders how to reconcile these results with those reported for green sunfish RPE [20] or melanophores $[27,29]$ showing that $\mathrm{Ca}^{2+}$ transients are neither necessary nor sufficient for pigment granule movement in either direction, i.e. aggregation or dispersion. One possibility is that the $\mathrm{Ca}^{2+}$ "requirement" for pigment granule dispersion in RPE can be bypassed or overruled by other mechanisms. For example, King-Smith et al. [20] observed that in RPE isolated from green sunfish pigment granule dispersion initiated by cAMP-washout could be accomplished in the absence of extracellular $\mathrm{Ca}^{2+}$, following depletion of intracellular stores by incubating RPE sheets in $\mathrm{Ca}^{2+}$-free medium, or damping changes in intracellular $\mathrm{Ca}^{2+}$ by infiltrating the cells with the $\mathrm{Ca}^{2+}$-chelator BAPTA. In any of these cases, $\mathrm{CAMP}_{\mathrm{i}}$ may have been attenuated in the cells by efflux through the activity of organic anion transporters in addition to basal activity of phosphodiesterases. Thus, a requirement for $\mathrm{Ca}^{2+}$-based reduction in either CAMP or phosphoproteins could be bypassed by a mechanism involving cAMP-efflux. RPE isolated from green sunfish seem to have a high basal phosphatase activity since treatment with okadaic acid is sufficient to induce pigment granule aggregation (García, unpublished results).

King-Smith et al. [20] also showed that elevating $\mathrm{Ca}^{2+}$ by treating cells with ionomycin was not sufficient to prevent aggregation when $1 \mathrm{mM}$ cAMP was added to the medium. Earlier work done by García and Burnside [18] suggested that cAMP was imported into RPE cells via organic anion transporters. Thus, given a sufficient gradient for import,
cAMP levels in the cell could remain high along with PKA activity, resulting in a continual phosphorylation of target proteins associated with pigment granule aggregation, even in the face of increased phosphodiesterase activity or phosphatase activity.

Also consistent with the results we report here suggesting that bluegill RPE express muscarinic receptors are the observations that human $[30,31]$ and rat [32] RPE express muscarinic receptors. The receptors on human RPE have been linked to phosphoinositide hydrolysis [30,31], suggesting that they belong to the $M_{1}, M_{3}$ or $M_{5}$ subclass or some combination of these subclasses. Based on pharmacological studies, Feldman et al. [30] concluded that $\mathrm{M}_{3}$ receptors are the subtype present on human RPE.

\section{Conclusions}

The pharmacological studies reported herein indicate the involvement of muscarinic acetylcholine receptors in carbachol-induced pigment granule dispersion in RPE isolated from bluegill, and further suggest that they belong to the odd-subtypes. This conclusion requires corroboration from on-going molecular studies and suggests further experiments to look at downstream signaling pathways.

\section{Methods \\ Fish maintenance}

Experiments were performed using protocols approved by the Institutional Animal Care and Use Committee. Bluegill (Lepomis macrochirus) were purchased from Johnson Lake Management, San Marcos, TX. Fish were kept in aerated 55-gallon aquaria on a 12 hour light/ 12 hour dark cycle room for at least two weeks prior to use.

\section{Isolation of RPE and drug treatments}

All experiments were carried out in dim, incandescent light ( $\leq 2$ lux). In order to facilitate isolation of RPE, fish were dark-adapted for thirty minutes in a light-tight box, prior to dissection during subjective midday (about 6 hours after light onset). Fish were killed by severing the spine followed by double pithing. Eyeballs were removed and hemisected, and the cornea, lens, vitreous humor, and the neural retina were discarded. RPE sheets were flushed out of the eyecup by applying a steady stream of modified Ringer's solution (isolation buffer). The isolation buffer contained $24 \mathrm{mM} \mathrm{NaHCO}^{-}{ }_{3}, 3 \mathrm{mM}$ HEPES (free acid), $116 \mathrm{mM} \mathrm{NaCl}, 5 \mathrm{mM} \mathrm{KCl}, 1 \mathrm{mM}$ $\mathrm{NaH}_{2} \mathrm{PO}_{4} . \mathrm{H}_{2} \mathrm{O}, 26 \mathrm{mM}$ dextrose, $1 \mathrm{mM}$ ascorbic acid, 0.8 $\mathrm{mM} \mathrm{MgSO}_{4}, 1 \mathrm{mM}$ EGTA, and $0.9 \mathrm{mM} \mathrm{CaCl}_{2}$. Free $\mathrm{Ca}^{2+}$ concentrations were estimated to be $10^{-5} \mathrm{M}$ (see $\left.[9,18]\right)$. The isolation buffer was gassed with a mixture of $95 \%$ air and $5 \% \mathrm{CO}_{2}$ for at least 15 minutes prior to and throughout the dissection to maintain the $\mathrm{pH}$ at 7.2. The RPE sheets were divided into 6 samples and incubated in 24 
Table 3: Cholinergic agonists and antagonists used in this study

\begin{tabular}{lll}
\hline Agonist & Site of Action & Induced Pigment Granule Dispersion \\
\hline Carbachol & MI-M5 & Yes \\
4-Chlorophenyl & MI & Yes \\
Arecaidine but-2-ynyl ester tosylate & M2 & No \\
\hline Antagonist & Site of Action & Blocked Pigment Granule Dispersion \\
\hline Atropine & MI-M5 & Yes \\
Pirenzepine & MI & Yes \\
AF-DX II6 & M2 & No \\
4-DAMP & M3 & Yes \\
Tropicamide & M4 & No \\
\hline
\end{tabular}

RPE was isolated from dark-adapted bluegill and, following incubation for 45 minutes in $10 \mu \mathrm{M}$ forskolin, was incubated an additional 45 minutes in increasing concentrations of agonist or in the presence of $100 \mathrm{nM}$ carbachol and increasing concentrations of antagonists. The agonists and antagonists tested and their efficacy are presented.

well plates in a humidified chamber according to the regimens described below.

Isolated RPE undergo pigment dispersion [18]; therefore, pigment granule aggregation in all samples was induced by a 45 -minute treatment with the adenylate cyclase stimulator, forskolin (Calbiochem, La Jolla, CA). Dose response analysis of forskolin was carried out using forskolin $(10 \mathrm{mM})$ resuspended in DMSO and then diluted serially in low calcium Ringer's solution to concentrations ranging from $0.1 \mu \mathrm{M}$ to $100 \mu \mathrm{M}$. Control tissues were incubated in low calcium Ringer's alone or in low calcium Ringer's with $0.01 \%$ DMSO.

For experiments to test the efficacy of cholinergic agonists and antagonists, following isolation, tissue was treated for 45 minutes with $10 \mu \mathrm{M}$ forskolin, after which forskolin was washed out 3 times using isolation buffer prior to further treatment with agonists and antagonists.

The effectiveness of various cholinergic agonists was evaluated by dose response analysis. Agonists (see Table 3 for list of agonists and antagonists) were prepared in isolation buffer or DMSO (arecaidine but-2-ynyl ester tosylate) and were applied following wash out of forskolin (see above). In order to maintain the $\mathrm{pH}$ (7.2) constant throughout the experiment, the tissue was incubated with agonist for 45 minutes in a humidified chamber gassed with a mixture of $95 \%$ air and $5 \% \mathrm{CO}_{2}$ on a gyratory shaker (50 rpm). Control tissue was incubated in low calcium Ringer's solution or for the experiments testing arecaidine in $0.01 \%$ DMSO. The cells were fixed by adding a $2 \times$ stock solution of fixative to the isolation buffer to achieve a final concentration of $0.5 \%$ glutaraldehyde,
$0.5 \%$ paraformaldehyde, and $0.8 \%$ potassium ferricyanide.

Separate experiments were conducted using antagonists, also prepared in isolation buffer, as a $2 \times$ stock solution. After washing out the forskolin with isolation buffer, antagonists (see Table 3) were applied, immediately followed by application of carbachol $(100 \mathrm{nM})$ in equal parts. After a 45-minute incubation, the RPE was fixed (see above).

\section{Preparation of tissue for measurement and statistical analysis}

After fixing the tissue overnight, individual RPE cells were dissociated by chopping the RPE sheets on a glass slide using a No. 1 coverslip. RPE fragments were then mounted on the slide and were viewed under a phase contrast microscope. The determination of pigment granule position was done by calculating pigment indices (PI) [14]. The pigment index is a ratio of the length of the cell occupied by pigment to the total length of the cell. Using an ocular micrometer, in most cases thirty cells per treatment per fish were measured and the mean PI was calculated. In four cases as few as nine cells per treatment per fish were measured, and the mean pigment index obtained was included in the analysis.

Dose response curves were plotted to determine if the agonist or antagonist treatment affected the pigment index. The pigment indices plotted are the average of the mean PI calculated (see above). The error bars represent the standard error of the mean. The $\mathrm{n}$ values represent the number of fish used in obtaining the data and is 4 fish unless otherwise noted. Statistical comparisons were made among pigment indices yielded from different 
concentrations of a single drug, but were not made among pigment indices yielded from treatment with different drugs. To determine if the treatment means were significantly different, one-way analysis of variance (one-way ANOVA) followed by Tukey's multiple comparison test was used with comparisons made using the summary data (the means from each fish from each treatment). To test if dispersion occurred in control samples (no agonist applied), treatment means between the forskolin sample and the control sample were analyzed using a Student's ttest. All statistical analyses were utilized assuming that the pigment indices were normally distributed and variances between means were equal. Statistical significance was reported when $\mathrm{p}<0.05$.

\section{List of abbreviations used}

4-CP 4-[N-(4-chlorophenyl) carbamoyloxy]-4-pent-2ammonium iodide

4-DAMP 4-diphenylacetoxy-N-methylpiperidine

5'-AMP 5'-adenosine monophosphate

AF-DX 116 11-[[[2-Diethylamino-O-methyl]-1-piperidinyl]acetyl]-5,11-dihydrol-6 $H$-pyridol $[2,3-b][1,4]$ benzodiazepine-6-one

ANOVA analysis of variance

BAPTA 1,2-bis-(o-Aminophenoxy)ethane-N,N,N',N'tetraacetic acid

Ca-CaM calcium-calmodulin complex

cAMP 3',5'-cyclic adenosine monophosphate

DMSO dimethylsulfoxide

EGTA Ethyleneglycotetraacetic acid

FSK forskolin

$\mathrm{G}_{\mathrm{i}}$ inhibitory GTP-binding protein

GSF green sunfish

HEPES 4-(2-hydroxyethyl)-1-piperazineethanesulfonic acid

IBMX isobutlymethlyxanthine

$\mathrm{IP}_{3}$ 1,4,5-inositol trisphosphate

$\mathrm{M}_{\text {even }}$ muscarinic acetylcholine receptor type 2, 4 or both
$M_{\text {odd }}$ muscarinic acetylcholine receptor type $1,3,5$ or some combination

OAT organic anion transport

PDE phosphodiesterase

PI pigment index

PKA cAMP-dependent protein kinase

$\mathrm{PKI}_{5-24}$ amide PKA-inhibitory peptide (amino acids 5-24) with amide adduct

PLC phospholipase C

Protein-P phosphoprotein

RPE retinal pigment epithelium

rpm rotations per minute

SEM standard error of the mean

\section{TX Texas}

\section{Authors' contributions}

AG conducted most of the pharmacological experiments, the statistical analysis and prepared a first draft of the manuscript. EC carried out the experiments testing the efficacy of tropicamide. DG conceived of and oversaw the project, secured funding, substantially revised the discussion and prepared the manuscript for publication.

\section{Acknowledgements}

The authors are grateful for help with the statistical analysis provided by Drs. James R. Ott and Butch Weckerly. The authors also wish to thank Dr. Joseph Koke for help in preparing figure I, and Drs. Koke and Simon Durdan and Mr. Prasad Phatarpekar for critically reading the manuscript. Finally, the authors thank Mr. Chad Copeland for proof-reading the final version. This study was funded primarily by a National Science Foundation research grant and REU supplements (IBN 00-77666, 01-322I2, and 0228857) and a teacher enhancement grant (ESIE 973I32I). Support was also provided by the National Institutes of Health through a Bridges to the Baccalaureate grant (GM 58375-0IAI).

\section{References}

I. Burnside B, Nagle BW: Retinomotor movements of photoreceptors and retinal pigment epithelium: mechanisms and regulation. Progress in Retinal Research Volume 2. Edited by: Osborne $\mathrm{N}$ and Chader G. New York, Pergamon Press; 1983:67-109.

2. Dearry A, Burnside B: Stimulation of distinct D2 dopaminergic and alpha 2-adrenergic receptors induces light-adaptive pigment dispersion in teleost retinal pigment epithelium. J Neurochem 1988, 51:1516-1523.

3. Rao NA, Wu GS: Free radical mediated photoreceptor damage in uveitis. Prog Retin Eye Res 2000, 19:41-68.

4. Dearry A, Burnside B: Light-induced dopamine release from teleost retinas acts as a light-adaptive signal to the retinal pigment epithelium. J Neurochem 1989, 53:870-878. 
5. Dearry A, Edelman JL, Miller S, Burnside B: Dopamine induces light-adaptive retinomotor movements in bullfrog cones via D2 receptors and in retinal pigment epithelium via DI receptors. J Neurochem 1990, 54:1367-1378.

6. Cote TE, Grewe CW, Kebabian JW: Stimulation of a D-2 dopamine receptor in the intermediate lobe of the rat pituitary gland decreases the responsiveness of the beta-adrenoceptor: biochemical mechanism. Endocrinology 1981, 1 08:420-426.

7. Douglas RH, Wagner HJ, Zaunreiter M, Behrens UD, Djamgoz MB The effect of dopamine depletion on light-evoked and circadian retinomotor movements in the teleost retina. Vis Neurosci 1992, 9:335-343.

8. Ball AK, Baldridge WH, Fernback TC: Neuromodulation of pigment movement in the RPE of normal and 6-OHDAlesioned goldfish retinas. Vis Neurosci 1993, 10:529-540.

9. Garcia D: Carbachol-induced pigment granule dispersion in teleost retinal pigment epithelium. Cytobios 1998, 94:3I-37.

10. Caulfield MP, Birdsall NJ: International Union of Pharmacology. XVII. Classification of muscarinic acetylcholine receptors. Pharmacol Rev 1998, 50:279-290.

II. Hsieh DJ, Liao CF: Zebrafish M2 muscarinic acetylcholine receptor: cloning, pharmacological characterization, expression patterns and roles in embryonic bradycardia. $\mathrm{Br} J$ Pharmacol 2002, 137:782-792.

12. Felder CC: Muscarinic acetylcholine receptors: signal transduction through multiple effectors. Faseb J 1995, 9:619-625.

13. Hosey MM: Diversity of structure, signaling and regulation within the family of muscarinic cholinergic receptors. Faseb J 1992, 6:845-852.

14. Bruenner U, Burnside B: Pigment granule migration in isolated cells of the teleost retinal pigment epithelium. Invest Ophthalmol Vis Sci 1986, 27: 1634-1643.

15. Jones SB, King LB: Muscarinic cholinergic receptors in brain and atrial membranes of adult brook trout (Salvelinus fontinalis) measured by radioligand binding techniques. Comp Biochem Physiol C Pharmacol Toxicol Endocrinol 1995, I I 2:43-50.

16. Tietje KM, Nathanson NM: Embryonic chick heart expresses multiple muscarinic acetylcholine receptor subtypes. Isolation and characterization of a gene encoding a novel $\mathrm{m}^{2}$ muscarinic acetylcholine receptor with high affinity for pirenzepine. J Biol Chem 1991, 266: I7382-17387.

17. Stein R, Pinkas-Kramarski R, Sokolovsky M: Cloned MI muscarinic receptors mediate both adenylate cyclase inhibition and phosphoinositide turnover. EMBO Journal 1988, 7:303 I-3035

18. Garcia DM, Burnside B: Suppression of cAMP-induced pigment granule aggregation in RPE by organic anion transport inhibitors. Invest Ophthalmol Vis Sci 1994, 35: 178-188.

19. Burnside $B$, Basinger S: Retinomotor pigment migration in the teleost retinal pigment epithelium. II. Cyclic-3',5'-adenosine monophosphate induction of dark-adaptive movement in vitro. Invest Ophthalmol Vis Sci 1983, 24:16-23.

20. King-Smith C, Chen P, Garcia D, Rey H, Burnside B: Calcium-independent regulation of pigment granule aggregation and dispersion in teleost retinal pigment epithelial cells. J Cell Sci 1996, I09 ( Pt I):33-43.

21. Haimo LT, Rozdzial MM: Lysed chromatophores: a model system for the study of bidirectional organelle transport. Methods Cell Biol 1989, 31:3-24.

22. Rozdzial MM, Haimo LT: Bidirectional pigment granule movements of melanophores are regulated by protein phosphorylation and dephosphorylation. Cell 1986, 47:1061-1070.

23. Rozdzial MM, Haimo LT: Reactivated melanophore motility: differential regulation and nucleotide requirements of bidirectional pigment granule transport. J Cell Biol 1986, 103:2755-2764.

24. Thaler CD, Haimo LT: Control of organelle transport in melanophores: regulation of $\mathrm{Ca2}+$ and cAMP levels. Cell Motil Cytoskeleton 1992, 22:175-184.

25. Thaler CD, Haimo LT: Regulation of organelle transport in melanophores by calcineurin. J Cell Biol 1990, I I I:1939-1948.

26. Rodionov V, Yi J, Kashina A, Oladipo A, Gross SP: Switching between microtubule- and actin-based transport systems in melanophores is controlled by cAMP levels. Curr Biol 2003, | 3:1837-|847.
27. Sammak PJ, Adams SR, Harootunian AT, Schliwa M, Tsien RY: Intracellular cyclic AMP not calcium, determines the direction of vesicle movement in melanophores: direct measurement by fluorescence ratio imaging. / Cell Biol 1992, I I7:57-72.

28. Tuma MC, Gelfand VI: Molecular mechanisms of pigment transport in melanophores. Pigment Cell Res 1999, I 2:283-294.

29. Kotz KJ, McNiven MA: Intracellular calcium and cAMP regulate directional pigment movements in teleost erythrophores. $J$ Cell Biol 1994, I 24:463-474.

30. Feldman EL, Randolph AE, Johnston GC, DelMonte MA, Greene DA: Receptor-coupled phosphoinositide hydrolysis in human retinal pigment epithelium. J Neurochem 199|, 56:2094-2100.

31. Osborne NN, FitzGibbon F, Schwartz G: Muscarinic acetylcholine receptor-mediated phosphoinositide turnover in cultured human retinal pigment epithelium cells. Vision Res |99|, 3I:III9-II 27.

32. Salceda R: Muscarinic receptors binding in retinal pigment epithelium during rat development. Neurochem Res 1994, 19:1207-1210.
Publish with BioMed Central and every scientist can read your work free of charge

"BioMed Central will be the most significant development for disseminating the results of biomedical research in our lifetime. "

Sir Paul Nurse, Cancer Research UK

Your research papers will be:

- available free of charge to the entire biomedical community

- peer reviewed and published immediately upon acceptance

- cited in PubMed and archived on PubMed Central

- yours - you keep the copyright
BioMedcentral 